\title{
The effects of plane of nutrition and environmental temperature on the energy metabolism of the growing pig
}

\author{
1. Heat loss and critical temperature
}

\author{
BY W. H. CLOSE AND L. E. MOUNT \\ $A R C$ Institute of Animal Physiology, Babraham, Cambridge CB2 $4 A T$ \\ (Received 28 November 1977 - Accepted I4 March 1978)
}

\begin{abstract}
I. The heat losses and energy balances of thirty-eight individually housed pigs (initial body-weights $2 \mathrm{I}-38 \mathrm{~kg}$ ) were measured continuously for periods of $14 \mathrm{~d}$ when they were maintained at environmental temperatures of $10,15,20,25$ or $30^{\circ}$. At each temperature four levels of feeding were given approximating to once, twice and three times the maintenance energy intake and the $a d$ lib. level. The minimal maintenance energy requirement (M) was calculated to be $440 \mathrm{~kJ}$ metabolizable energy (ME) $/ \mathrm{kg}^{0.75}$ per d at $25^{\circ}$.

2. ME intake at the ad lib. level decreased from $1965 \mathrm{~kJ} / \mathrm{kg}^{0.75}$ per d at $10^{\circ}$ to 1202 at $30^{\circ}$.

3. Heat loss calculated from multiple regression analysis decreased to minimum levels between 20 and $25^{\circ}$; $30^{\circ}$ was within the hyperthermic zone at each plane of nutrition.

4. The partition of heat loss into its sensible and evaporative components showed that evaporation increased from $25 \%$ at $10^{\circ}$ to $78 \%$ at $30^{\circ}$.

5. Critical temperature was dependent upon food intake and decreased from $23 \cdot 1^{\circ}$ at $\mathrm{M}$ to $20 \cdot 7^{\circ}$ at $2 \mathrm{M}$, $18.0^{\circ}$ at $3 \mathrm{M}$ and $16.7^{\circ}$ at $4 \mathrm{M}$.

6. The extra food required to meet extra thermoregulatory heat production per $1^{\circ}$ below the effective critical temperature was $0.65 \mathrm{~g} / \mathrm{kg}$ body-weight per $\mathrm{d}$.
\end{abstract}

Plane of nutrition and environmental temperature have marked effects on the rate of heat loss from the growing pig (Holmes \& Mount, I967; Close, Mount \& Start, 1971 ; Fuller \& Boyne, 1972; Verstegen, Close, Start \& Mount, 1973; Monteith \& Mount, 1974; Blaxter, 1977; Holmes \& Close, 1977); these effects are relative to the animal's critical temperature. The critical temperature, defined as the air temperature at the lower end of the zone of thermal neutrality, is of particular interest because for any given plane of nutrition it is the lowest environmental temperature at which the animal's heat loss is minimal and consequently at which energy retention for production is maximal.

In pig production it is therefore useful to know the critical temperatures that are associated with different planes of nutrition. It is also useful to know the extent to which a lower environmental temperature causes an increase in heat production and a reduction in the supply of nutrients available for growth. The experiments reported here were designed to provide this information for pigs maintained at several planes of nutrition and exposed individually to a range of standardized thermal environments.

This work has been the subject of a preliminary communication (Close \& Mount, 1976).

\section{MATERIALS AND METHODS}

\section{Animals}

As in previous experiments (Close \& Mount, 1975) the animals were all castrated Large White pigs, free of enzootic pneumonia. After weaning at 6 weeks of age the animals were removed to temperature-controlled pens where they remained until selected for experiment within the body-weight range $20-40 \mathrm{~kg}$. At the start of the experiments the actual bodyweights ranged from $2 \mathrm{I} \cdot 7$ to $38 \cdot 2 \mathrm{~kg}$; at the end of the experiments they were between $24 \cdot 2$ and $50.0 \mathrm{~kg}$. The variation in final body-weight was due mainly to the extremes of feeding imposed upon the animals. 
Table I. Mean body-weights, food intakes, metabolizable energy (ME) intake and heat losses $(H)$ of the experimental animals at each environmental temperature

$\begin{array}{ccccc}\begin{array}{c}\text { Environmental } \\ \text { temperature } \\ \text { (deg) }\end{array} & \begin{array}{c}\text { Body-wt } \\ (\mathrm{kg})\end{array} & \begin{array}{c}\text { Food intake } \\ (\mathrm{g} / \mathrm{d})\end{array} & \begin{array}{c}\text { ME intake } \\ \left(\mathrm{kJ} / \mathrm{kg}^{0.75} \mathrm{per} \mathrm{d}\right)\end{array} & \begin{array}{c}H \\ \left(\mathrm{~kJ} / \mathrm{kg}^{0 \cdot 75} \text { per d) }\right.\end{array} \\ \text { I0 } & 31 \cdot 2 & 642 & 571 & 593 \\ & 35 \cdot 0 & 1189 & 976 & 760 \\ & 40 \cdot 7 & 2034 & 1446 & 785 \\ & 34 \cdot 4 & 2407 & 1965 & 1009 \\ 15 & 29 \cdot 7 & 540 & 504 & 604 \\ & 24 \cdot 6 & 840 & 893 & 67 \mathrm{I} \\ & 35 \cdot 3 & 1776 & 1476 & 763 \\ & 38 \cdot 3 & 2080 & 1591 & 854 \\ 20 & 27 \cdot 5 & 506 & 495 & 469 \\ & 30 \cdot 4 & 1007 & 943 & 601 \\ & 31 \cdot 7 & 1606 & 1412 & 792 \\ & 37 \cdot 3 & 2113 & 1655 & 863 \\ 25 & 30 \cdot 3 & 495 & 455 & 425 \\ & 30 \cdot 5 & 1036 & 941 & 588 \\ & 34 \cdot 7 & 1754 & 1494 & 763 \\ & 37 \cdot 7 & 1843 & 1406 & 714 \\ 30 & 30 \cdot 4 & 493 & 455 & 484 \\ & 29 \cdot 2 & 986 & 928 & 637 \\ & 32 \cdot 5 & 1397 & 1202 & 765\end{array}$

\section{Plan of experiments}

The experiments were designed in a $5 \times 4$ factorial arrangement, involving five temperatures with four levels of feeding at each temperature. However, only three levels of feeding were given at the highest environmental temperature due to the reduced appetite of the pig under hot conditions. There were therefore nineteen combinations of temperature and feeding level, and, as each treatment was duplicated, this involved a total of thirty-eight animals, each animal being exposed to only one combination. The environmental temperature for each animal was maintained at $10,15,20,25$ or $30^{\circ}\left( \pm 0.2^{\circ}\right)$ throughout the duration of each experiment. These temperatures were selected to give a range above and below the expected critical temperatures. At each temperature one of four levels of feeding was given representing intakes of approximately once, twice, and three times the maintenance energy intake, while the fourth level corresponded to the ad lib. intake.

The daily food intake for maintenance was estimated initially to be approximately $\mathrm{I} \cdot 7 \%$ of the body-weight. Thus the actual levels of feeding employed at the twice and three times maintenance intakes were 34 and $5 \mathrm{I} \mathrm{g}$ food $/ \mathrm{kg}$ body-weight per $\mathrm{d}$. At the lowest level of feeding, the maintenance level, the food allowance was adjusted so that the body-weight of the animals remained as nearly constant as possible throughout the course of the experiment, so allowing comparison of energy maintenance with body-weight maintenance. At the highest level of intake, the ad lib. level, food was available to appetite at all times and enough food was provided to ensure that there were always food refusals. At 10,15 and $20^{\circ}$, the animal's ad lib. intake was greater than $5 \mathrm{I} \mathrm{g}$ food $/ \mathrm{kg}$ body-weight per $\mathrm{d}$; at $25^{\circ}$ it was equivalent to $5 \mathrm{I} \mathrm{g}$ food $/ \mathrm{kg}$ body-weight per $\mathrm{d}$, while at $30^{\circ}$ there were always food refusals at this feeding level. There were, therefore, four levels of feeding at each of the environmental temperatures of $10,15,20$ and $25^{\circ}$, while at $30^{\circ}$ only three levels were applied corresponding to once and twice the calculated maintenance energy requirement and the ad lib. level. The plan of the experiment, together with the actual amount of food consumed, is given in Table I. 


\section{Feeding}

The animals were given a commercial 'growers' diet based on barley, wheat, wheat meal and soya-bean meal with added vitamin and mineral supplements. No growth-promoting substances were included in the dietary formulation. Each week throughout the duration of the experiments samples of food were collected for analysis. The food supplied $18 \cdot 2( \pm 0 . \mathrm{I}) \mathrm{g}$ crude protein (nitrogen $\times 6.25) / \mathrm{kg}$ dry matter $(\mathrm{DM})$ and $13.4( \pm 0 . \mathrm{I}) \mathrm{MJ}$ metabolizable energy (ME) $/ \mathrm{kg}$ DM. The food offered to the animals was weighed out three times each week and was calculated on the basis of expected gain in body-weight between weighing periods. The animals had access to an ad lib. supply of water, and both food and water were kept at the same temperature as that of the calorimeter. The food was offered dry in pelleted form and was divided into equal feeds given morning and afternoon, at 09.00 and 17.00 hours. Any food spilled or refused by the animals was collected, weighed, sampled and stored in a cold room until analysed at the end of each experiment.

\section{Experimental routine}

At 2 weeks before their introduction into the calorimeter, the pigs were removed to individual mobile pens kept in temperature-controlled rooms maintained at the same temperature as the calorimeter (Close \& Mount, 1975). The feeding level was adjusted to that of the experiment; before this all animals had been fed in groups at $45 \mathrm{~g}$ food $/ \mathrm{kg}$ body-weight per $d$. All animals were in this way exposed to the plane of nutrition and environmental temperature for the particular experiment for the 2 weeks preceding their entry into the calorimeter, which, in all instances, was on a Wednesday morning. The animals, in their mobile pens, were wheeled into the calorimeter where heat loss and other quantities were recorded for a $\mathrm{I} 4 \mathrm{~d}$ period. During this period the mobile pens were changed each Monday, Wednesday and Friday morning, a process that was completed within $15 \mathrm{~min}$; at this time, the animals were weighed and their rectal temperatures measured.

\section{Measurements made and definitions of derived quantities}

Calorimetry and heat loss. The calorimeters used for the present investigation were of the direct, heat-sink type (Mount, Holmes, Start \& Legge, 1967; Close \& Mount, 1975). Total heat loss $(H)$ and its sensible and evaporative components were recorded continuously throughout the $\mathrm{I} 4 \mathrm{~d}$ period and calculated as the mean hourly rate for each $24 \mathrm{~h}$ period. At $10^{\circ}$, the mean water vapour pressure was $\mathrm{I} 0 \mathrm{mbar}$ (relative humidity, $8 \mathrm{I} \pm 2 \%$ ), at $30^{\circ}$ it was 20 mbar (relative humidity, $47 \pm 2 \%$ ) with intermediate values at 15,20 and $25^{\circ}$.

Energy balance. Simultaneously with the measurement of heat loss, determinations were made of energy balance. For this purpose each experiment was divided into two consecutive $7 \mathrm{~d}$ collection periods. Collections of food, food refused, faeces, urine and washings were made during each period and were analysed independently for their energy content. There were two separate estimates of energy balance for each animal, giving a total of four estimates for each treatment.

Collection of excreta. The mobile pens were equipped with hardwood slatted floors, and a draining base for the collection of urine in a receptacle containing $50 \mathrm{ml} \mathrm{M}$-sulphuric acid. The urine receptacle was changed each morning and the contents were bulked and stored at $5^{\circ}$ until analysed at the end of each $7 \mathrm{~d}$ collection period. Faeces voided by the animals were collected from the hardwood slats each Monday, Wednesday and Friday morning, immediately after the changing of the mobile pens. The pens were washed and both faeces and washings were bulked and stored at $5^{\circ}$ until analysed. Samples of both food and food refused or spilled were also collected and stored. The ME intakes were determined from the differences between the energy values of the food intakes on the one side and those of the faeces, urine 
and washings, and methane, on the other. Methane formation was calculated as $0.6 \%$ of the gross energy (GE) intake (Breirem, I935; Verstegen, I97I).

\section{RESULTS}

\section{Food intake}

As a percentage of the GE in the diet, the ME intake was independent of both environmental temperature and plane of nutrition. Increasing the level of food intake at each environmental temperature caused a small but non-significant $(P>0.05)$ reduction in the metabolizability of the diet. Thus at $20^{\circ}$, the mean ( $\pm \mathrm{SE}$ ) values were $0.752 \pm 0.001,0.754 \pm 0.007$, $0.747 \pm 0.006$ and $0.731 \pm 0.015$ at food intakes equivalent to once, twice and three times the calculated maintenance requirement and $a d l i b$. respectively. There was also no difference $(P>0.05)$ in metabolizability either within or between each combination of temperature and plane of nutrition. The mean ( $\pm \mathrm{SE}$ ) metabolizability of the food was $0.737 \pm 0.006$, $0.76 \mathrm{I} \pm 0.003,0.746 \pm 0.005,0.76 \mathrm{I} \pm 0.00 \mathrm{I}$ and $0.760 \pm 0.005$ at $10,15,20,25$ and $30^{\circ}$.

The $a d \mathrm{lib}$. intake decreased with increase in temperature from $167.5 \pm 2.4 \mathrm{~g}$ food $/ \mathrm{kg}^{0.75}$ $(70 \mathrm{~g} / \mathrm{kg})$ per $\mathrm{d}$ at $10^{\circ}$ to $103.9 \pm 7.1 \mathrm{~g}$ food $/ \mathrm{kg}^{0.75}(43 \mathrm{~g} / \mathrm{kg})$ per $\mathrm{d}$ at $30^{\circ}$. This led to a reduction in $\mathrm{ME}$ intake from $1965 \pm 38 \mathrm{~kJ} / \mathrm{kg}^{0.75}$ per d at $10^{\circ}$ to $1202 \pm 50 \mathrm{~kJ} / \mathrm{kg}^{0.75}$ per d at $30^{\circ}$ (Table I).

\section{Heat loss}

The mean values of $H$ are given for each pair of animals in Table I, together with the corresponding ME intakes. In general, there was good agreement in $H$ between replicates within each treatment: in most instances the variation was less than $10 \%$, and only at the lowest level of feeding at 10 and $15^{\circ}$ did the differences exceed this amount.

The results were examined in terms of the multiple regression equation that gave the minimum residual variation:

$$
\begin{gathered}
H=979.8-50.33 T+0.9187 T^{2}+0.1366 \mathrm{ME}+0.0077(\mathrm{ME})(T) \\
( \pm 149.9)( \pm 12.45)( \pm 0.256) \quad( \pm 0.0715) \quad( \pm 0.0034)
\end{gathered}
$$

where $H$ is heat loss $\left(\mathrm{kJ} / \mathrm{kg}^{0.75}\right.$ per d), $T$ is environmental temperature (deg), and $\mathrm{ME}$ is $\mathrm{ME}$ intake ( $\mathrm{kJ} / \mathrm{kg}^{0.75}$ per d). $R$ (correlation coefficient) was 0.898 and the residual mean square at temperatures above $10^{\circ}$ was 1955 ( $\left.33 \mathrm{df}\right)$.

Values for $H$ were calculated at intakes approximating to once $(\mathrm{M})$, twice $(2 \mathrm{M})$, three $(3 \mathrm{M})$ and four times $(4 \mathrm{M})$ the thermoneutral maintenance energy requirement. The thermoneutral maintenance requirement has been calculated from the present results to be $440 \mathrm{~kJ} / \mathrm{kg}^{0.75}$ per $d$ at an environmental temperature of $25^{\circ}$ (Close, 1978), and this has been taken as the value for $M$. The relations of heat loss to environmental temperature at the four levels of $M E$ intake are shown in Fig. I.

The environmental temperature at which $H$ decreased to a minimum was dependent on the level of feeding, decreasing from approximately $25^{\circ}$ at $\mathrm{M}$ to $20^{\circ}$ at $4 \mathrm{M}$ (Fig. I). Changes in $H$ between 10 and $20^{\circ}$ were greater at $\mathrm{M}$ and $2 \mathrm{M}$ than at $3 \mathrm{M}$ and $4 \mathrm{M}$ levels of feeding. Increasing the environmental temperature above $25^{\circ}$ was associated with an increase in $H$ and suggested that $30^{\circ}$ was within the hyperthermal zone at each level of feeding. Level of food intake had a significant influence on $H$ at each environmental temperature with the result that each $440 \mathrm{~kJ} / \mathrm{kg}^{0.75}$ per d increase in $\mathrm{ME}$ intake was associated with a significant increase in $H$.

\section{Partition of heat loss}

The changes in the sensible (non-evaporative) and evaporative components of heat loss, in response to both temperature and level of feeding, are shown in Fig. 2. Sensible heat loss is large and related to food intake at the lower temperatures, whereas evaporative heat loss is 


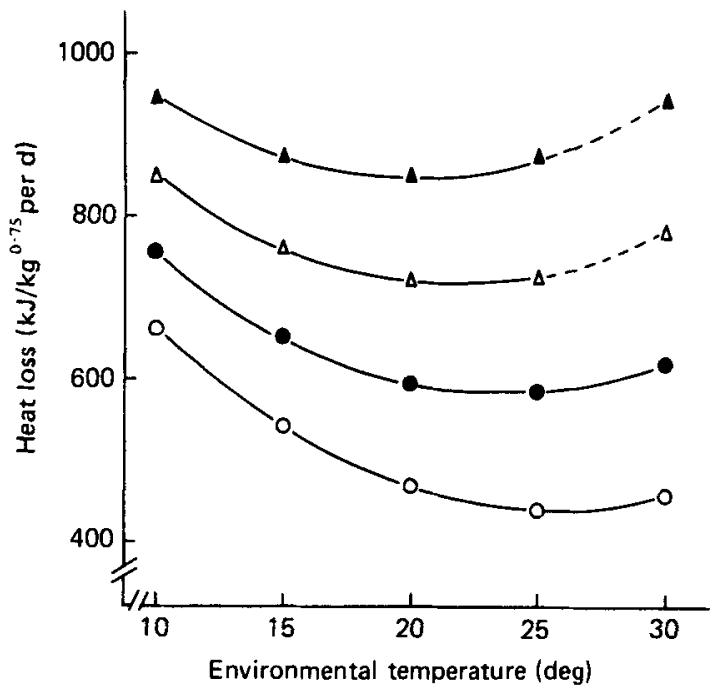

Fig. I. Heat loss $\left(\mathrm{kJ} / \mathrm{kg}^{0.75}\right.$ per $\mathrm{d}$ ) of growing pigs in relation to environmental temperature (deg) and metabolizable energy (ME) intake $\left(\mathrm{kJ} / \mathrm{kg}^{0.75}\right.$ per d). Rates of heat loss derived from multivariate regression analysis. $(\mathrm{O}-\mathrm{O}), 440 ;(\bigcirc-0), 880 ;(\triangle-\triangle), 1320 ;(\Delta-\Delta), 1760 \mathrm{~kJ} \mathrm{ME} / \mathrm{kg}^{0.75}$ per d. (-..--), Predicted values above the ad lib. intake of the animals.

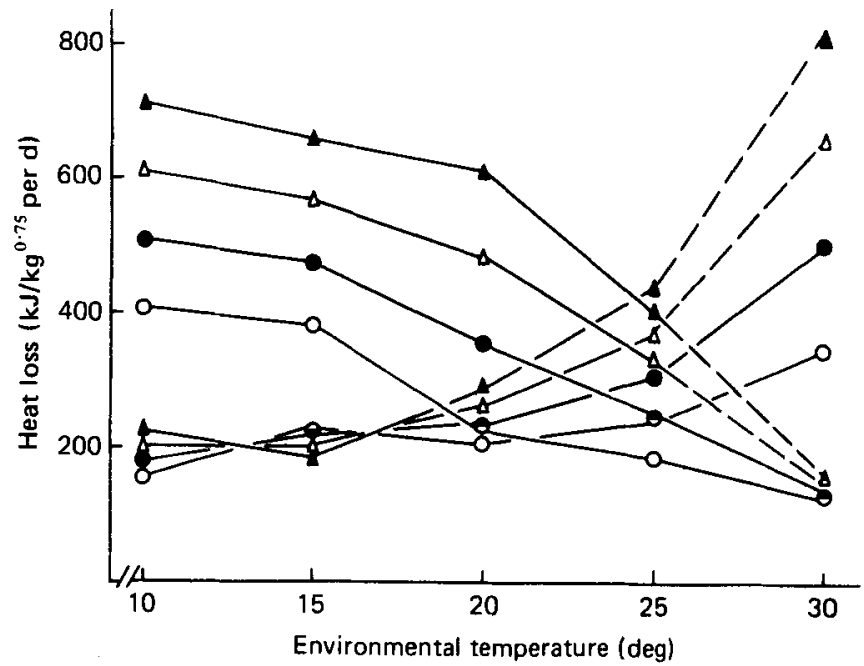

Fig. 2. Partition of heat loss $\left(\mathrm{kJ} / \mathrm{kg}^{0.75}\right.$ per $\mathrm{d}$ ) into sensible (decreasing with increase in environmental temperature) and evaporative (increasing with increase in environmental temperature) components for pigs in relation to environmental temperature (deg) and metabolizable energy (ME) intake $\left(\mathrm{kJ} / \mathrm{kg}^{0.75}\right.$ per d). (O-O), 440; $(-0), 880 ;(\triangle-\triangle), 1320 ;(\Delta-\Delta), 1760 \mathrm{~kJ} \mathrm{ME} / \mathrm{kg}^{0.75}$ per d. (...-), predicted values above the ad lib. intake of the animals.

large and related to food intake at the higher temperatures. Between 10 and $20^{\circ}$ evaporation showed little variation with increase in $\mathrm{ME}$ intake and the mean $( \pm \mathrm{SE})$ increase was equivalent to $0.02 \pm 0.03 \mathrm{~kJ} / \mathrm{kJ} \mathrm{ME}$. Increasing the environmental temperature resulted in increased rates of evaporation. The evaporative component represents moisture loss from the pen as a whole, that is not only from the animals but also evaporation from the faeces and urine voided by the animal within the calorimeter. 
竎

s

ธั้

需

齐

है है

o

की

$\therefore$

$\underset{8}{*}$

है

\&

उ

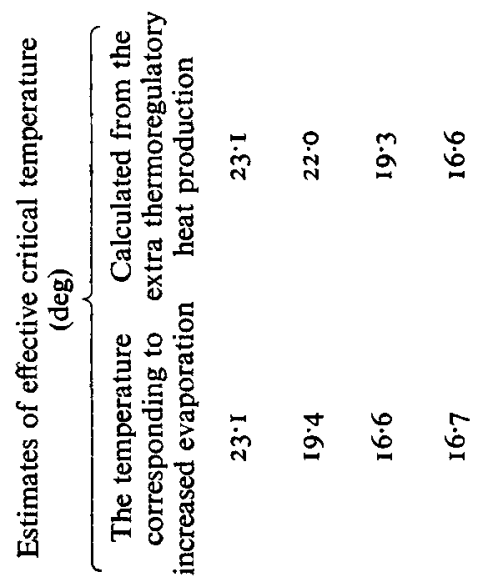

这

है

章

$\checkmark$

בิ

क 8

कर

bo

골

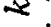

콩

宊

ร)

8

5

ิิ ชั

క

के

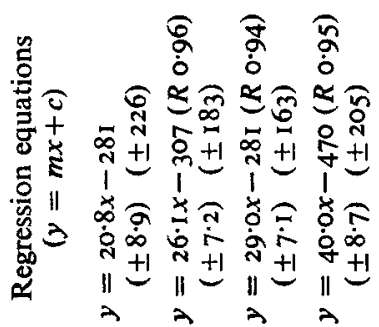

ธ

5

ㅎํㅇ

ร :

ป

$+2$

$\frac{2}{5} \approx$

兽

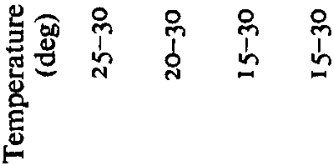

(i)

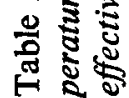

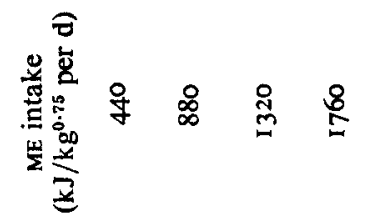


In general, sensible heat loss decreased and evaporation increased at each feeding level as environmental temperature was increased. Unlike sensible heat loss, evaporation was independent of both environmental temperature and plane of nutrition at environmental temperatures of 10 and $15^{\circ}$, and the mean $\left( \pm \mathrm{SE}\right.$ ) value corresponded to $200 \pm 8 \mathrm{~kJ} / \mathrm{kg}^{0.75}$ per $d$. This represented the minimal level of evaporation under the present experimental conditions, and was equivalent to a water loss of $1130 \mathrm{~g} / \mathrm{d}$ for a $35 \mathrm{~kg}$ pig. Under fasting conditions in similar mobile pens, Close \& Mount (I975) found a minimum evaporative loss of $211 \mathrm{~kJ} / \mathrm{kg}^{0.75}$ per d at 20 and $30^{\circ}$, equivalent to a water loss of $1190 \mathrm{~g} / \mathrm{d}$. Above $15^{\circ}$ the rate of increase of evaporation, and the temperature at which it increased above the minimum level, was dependent on the plane of nutrition. Although no abrupt changes in slope occur in Fig. 2, inspection indicates that the environmental temperature at which evaporation markedly increased changed from approximately $25^{\circ}$ at $\mathrm{M}$ to $15^{\circ}$ at $3 \mathrm{M}$ and $4 \mathrm{M}$. Above these temperatures, the increased evaporation $/ \mathrm{I}^{\circ}$ increase in temperature is indicated by the regression coefficients in Table 2. The environmental temperature at which increased evaporation occurred was calculated by substituting the minimal level of evaporation into each equation presented in Table 2. It decreased with increase in feeding level from $23 \cdot I^{\circ}$ at $\mathrm{M}$ to $\mathrm{I} 6 \cdot 6^{\circ}$ at $4 \mathrm{M}$.

As a proportion of the total, the amount of heat occurring as either sensible or evaporative loss remained relatively constant at each environmental temperature, irrespective of the level of feeding. Increasing the environmental temperature resulted in a significant increase in the evaporative component from $25( \pm 1) \%$ at $10^{\circ}$ to $78( \pm 2) \%$ at $30^{\circ}$. The temperature at which sensible and evaporative loss were similar, that is $50 \%$ of total heat loss, decreased as level of feeding was increased.

\section{Rectal temperature}

Mean $( \pm S E)$ rectal temperature varied within the range $38.7 \pm 0.10$ to $40.2 \pm 0.13^{\circ}$. Rectal temperature increased with level of feeding, but there was little variation within each temperature treatment.

\section{DISCUSSION}

\section{Heat loss}

Under the conditions of these experiments the calculated minimal rates of heat loss occurred between 20 and $25^{\circ}$, depending upon plane of nutrition. This is demonstrated in Fig. I, where it is also evident that $30^{\circ}$ was in the hyperthermic zone for all planes of nutrition. A generalization that is often applicable is that in the zone of thermal neutrality the plane of nutrition is the chief determinant of heat loss, whereas below the critical temperature the environmental temperature is the chief determinant (Graham, Wainman, Blaxter \& Armstrong, I959; Verstegen et al. 1973; Mount, 1976). The present results conform with this pattern only to the extent that a given range of $M E$ is associated with a smaller range of heat loss at lower temperatures than at higher temperatures, the value for range of heat loss: range of ME being 0.21 at $10^{\circ}$ and 0.37 at $30^{\circ}$.

\section{The estimation of critical temperature}

The results of these experiments can be used in two ways to calculate the effective critical temperatures for pigs fed on different planes of nutrition. First, estimates of critical temperature can be calculated according to the method outlined by Mount, Close \& Verstegen (1973). This method presupposes a knowledge of the extra thermoregulatory heat (ETH) 


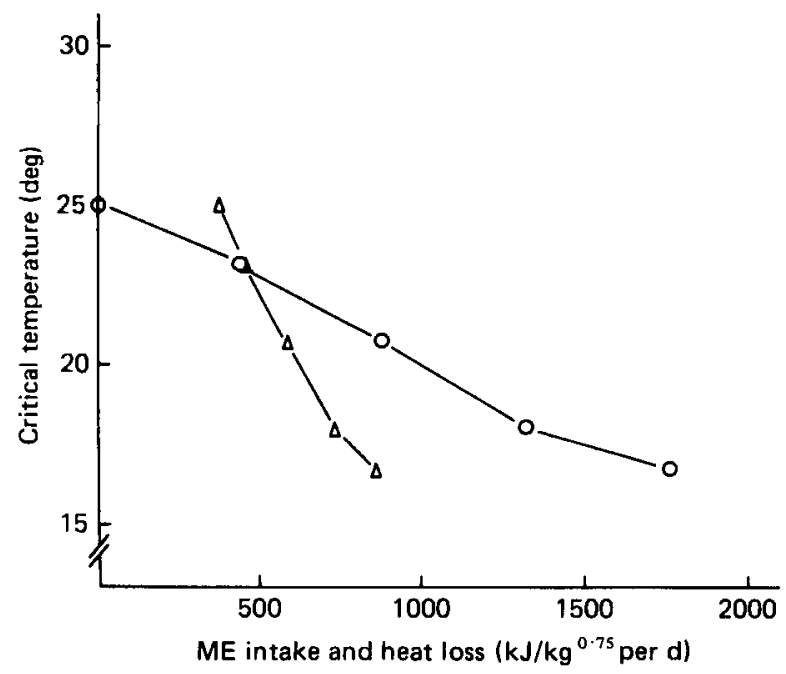

Fig. 3. The relation between critical temperature (air temperature at the lower end of thermal neutrality; deg), metabolizable energy (ME) intake $\left(\mathrm{kJ} / \mathrm{kg}^{0.75}\right.$ per d), $(\mathrm{O}-\mathrm{O})$, and heat loss $\left(\mathrm{kJ} / \mathrm{kg}^{0.75}\right.$ per $\left.\mathrm{d}\right),(\triangle-\triangle)$, for individual pigs between 20 and $50 \mathrm{~kg}$ body-weight.

produced as a result of a cold environment, and also of the rate of increase in heat loss below the critical temperature. The former has been calculated from the heat loss, energy retention and maintenance requirement in the way described by Verstegen et al. (1973). The rate of increase in heat loss below thermal neutrality has been taken as the rate of increase in maintenance heat loss, $\mathrm{I}^{8.9} \mathrm{~kJ} / \mathrm{kg}^{0.75}$ per $\mathrm{d}$ per $\mathrm{I}^{\circ}$ from the present results. Values of ETH have been calculated from the regression equation for a temperature of $15^{\circ}$. These values were I 54, I 33, 8I and $30 \mathrm{~kJ} / \mathrm{kg}^{0.75}$ per d at ME intakes of $440,880, \mathrm{I} 320$ and I $760 \mathrm{~kJ} / \mathrm{kg}^{0.75}$ per d. As a proportion of ME intake, ETH decreases from $35 \%$ at $M$ to $I 6,6$ and $I \cdot 7 \%$ at $2 \mathrm{M}, 3 \mathrm{M}$ and $4 \mathrm{M}$ respectively. Critical temperatures $\left(T_{c}\right)$, on each plane of nutrition, have been calculated from the equation:

$$
T_{\mathrm{c}}=\mathrm{I} 5+\frac{\mathrm{ETH}}{\mathrm{I} 8 \cdot 9},
$$

to give values of $23 \cdot \mathrm{I}, 22 \cdot 0,19 \cdot 3$ and $16 \cdot 6^{\circ}$ at ME intakes of $440,880,1320$ and $1760 \mathrm{~kJ} / \mathrm{kg}^{0.75}$ per $\mathrm{d}$ respectively.

It has been suggested that an environment cannot be considered as thermally neutral where the rate of evaporation has increased markedly through panting or sweating, although heat loss may be minimal (Mount, I974). Consequently, the second method of calculation of effective critical temperature is to use the temperatures at which marked increases in evaporation occur. These values are given in Table 2 where they are compared with those calculated from ETH. The mean values determined from the separate methods are given in Fig. 3, which also includes previous estimates of fasting critical temperature $\left(25^{\circ}\right)$ for pigs of similar size (McCracken \& Gray, 1972; Close \& Mount, 1975). Over this range of critical temperature, ME intake increased by $20 \mathrm{I} \mathrm{kJ} / \mathrm{kg}^{0.75}$ per $\mathrm{d}$ per $\mathrm{I}^{\circ}$ decrease in critical temperature, equivalent to $6.9 \mathrm{~g}$ food $/ \mathrm{kg}$ body-weight per $\mathrm{d}$ for a $35 \mathrm{~kg}$ pig. Heat loss increased by $57 \mathrm{~kJ} / \mathrm{kg}^{0.75}$ per $d$ per $I^{\circ}$, so that energy retention increased by $144 \mathrm{~kJ} / \mathrm{kg}^{0.75}$ per $\mathrm{d}$ per $\mathrm{I}^{\circ}$, representing an efficiency of utilization of energy of 0.72 within the zone of thermal neutrality, a value similar to that found by others (Nehring, Schiemann, Hoffman \& Klippel, 1960; Fuller \& Boyne, I972; Verstegen et al. 1973). 
From the extra thermoregulatory heat production at $15^{\circ}$, to maintain the same rate of energy retention in the cold as in the warm, the required rate of increase in food intake for $\mathrm{I}^{\circ}$ decrease below the apparent critical temperature is $0.65 \mathrm{~g}$ food $/ \mathrm{kg}$ body-weight per $\mathrm{d}$ for the solitary pig. Comparable values for animals of similar size kept in groups of four (Verstegen et al. 1973) and nine (Verstegen \& van der Hel, 1974) are 0.5 and $0.3 \mathrm{~g} / \mathrm{kg}$ body-weight per d per $I^{\circ}$ below the effective critical temperature. Increasing the group size within this range thus reduces the amount of extra food needed for ETH in the cold by approximately $7 \%$ per additional animal.

The authors thank Mr D. Brown (ARC Statistics Group, Cambridge) for the statistical analysis of the results, Mr I. B. Start for the assistance which he provided throughout the experiments and Dr J. Y. F. Paterson for assistance with computer programming.

\section{REFERENCES}

Blaxter, K. L. (1977). In Nutrition and the Climatic Environment, p. I [W. Haresign, H. Swan and D. Lewis, editors]. London: Butterworths.

Breirem, K. (1935). Beretn. Forsøgslab. no. I62.

Close, W. H. (1978). Br. J. Nutr. 40, 433.

Close, W. H. \& Mount, L. E. (1975). Br. J. Nutr. 34, 279.

Close, W. H. \& Mount, L. E. (1976). Proc. Nutr. Soc. 35, 60A.

Close, W. H., Mount, L. E. \& Start, I. B. (1971). Anim. Prod. 13, 285.

Fuller, M. F. \& Boyne, A. W. (1972). Br. J. Nutr. 28, 373.

Graham, N. McC., Wainman, F. W., Blaxter, K. L. \& Armstrong, D. G. (1959). J. agric. Sci., Camb. $52,13$.

Holmes, C. W. \& Close, W. H. (1977). In Nutrition and the Climatic Environment, p. 5I [W. Haresign, H. Swan and D. Lewis, editors]. London: Butterworths.

Holmes, C. W. \& Mount, L. E. (1967). Anim. Prod. 9, 435.

McCracken, K. J. \& Gray, R. (1972). Proc. Br. Soc. Anim. Prod. I, I 39.

Monteith, J. L. \& Mount, L. E. (editors) (1974). In Heat Loss from Animals and Man. London: Butterworths.

Mount, L. E. (1974). In Heat Loss from Animals and Man, p. 425 [J. L. Monteith and L. E. Mount, editors]. London: Butterworths.

Mount, L. E. (1976). Proc. Nutr. Soc. 35, 81.

Mount, L. E., Close, W. H. \& Verstegen, M. W. A. (1973). Proc. Nutr. Soc. 32, 71 A.

Mount, L. E., Holmes, C. W., Start, I. B. \& Legge, A. J. (I967). J. agric. Sci., Camb. 68, 47.

Nehring, K., Schiemann, R., Hoffman, L. \& Klippel, W. (1960). Archs Tierernähr. 10, 275.

Verstegen, M. W. A. (197I). Meded. LandbHogesch., Wageningen p. 71.

Verstegen, M. W. A., Close, W. H., Start, I. B. \& Mount, L. E. (1973). Br. J. Nutr. 30, 2 I.

Verstegen, M. W. A. \& van der Hel, W. (1974). Anim. Prod. 18, 1. 